\title{
Attitude towards the Teaching Profession: The Secondary School Teachers' Outlook
}

\author{
Lydia I. Eleje ${ }^{1, * \oplus}$, Ifeoma C. Metu ${ }^{2}$, Ngozi E. Ezenwosu ${ }^{3}$, Judith C. Ifeme ${ }^{4}$ \\ ${ }^{1}$ Evaluation, Research and Statistics Unit, Department of Educational Foundations, Faculty of Education, \\ Nnamdi Azikiwe University, Awka Anambra State, Nigeria \\ 2 Department of Educational Foundations, Faculty of Education, Nnamdi Azikiwe University, Awka, Anambra \\ State, Nigeria \\ ${ }^{3}$ Curriculum Unit, Department of Educational Foundations, Nnamdi Azikiwe University, Awka, Nigeria \\ ${ }^{4}$ Department of Educational Foundations, Nnamdi Azikiwe University, Awka, Nigeria \\ ${ }^{*}$ Correspondence: ijeomaexcite@gmail.com
}

How to cite this paper: Eleje, L. I., Metu, I. C., Ezenwosu, N. E., \& Ifeme, J. C. (2022). Attitude towards the Teaching Profession: The Secondary School Teachers' Outlook. Open Journal of Educational Research, 2(1), 23-31. Retrieved from https://www.scipublications.com/journal/index.php/ojer/article/view/205

Received: December 16, 2021 Accepted: February 21, 2022 Published: February 22, 2022

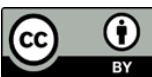

Copyright: (C) 2022 by the authors. Submitted for possible open access publication under the terms and conditions of the Creative Commons Attribution (CC BY) license (http://creativecommons.org/licenses /by/4.0/).

\begin{abstract}
Investigated in this study is the attitude of secondary school teachers towards the teaching profession. Survey design was adopted for the study and three research questions guided the study. The sample of the study comprises of all the 55 secondary school teachers of Senior Secondary 2 (SS2) in urban and rural schools, in Awka South Local Government Area, Anambra State. The instrument for data collection was a 20 item questionnaire developed by the researchers. The data collected was analyzed by computing mean and standard deviation. The findings of the study revealed that the majority of the secondary school teachers possessed positive attitude towards the teaching profession. It was also found that the female secondary school teachers had more positive attitude towards the profession than the male secondary school teachers. Furthermore, the secondary school teachers in urban areas had higher positive attitude than the secondary school teachers in rural areas. Based on the findings of the study, it was recommended that both the government and teacher organization should see to the training, retraining and motivation of secondary school teachers. If they are well-trained and motivated, they will be more committed and learning will be enhanced.
\end{abstract}

Keywords: Attitude, Secondary school, Education, Teachers, Teaching profession

\section{Introduction}

Education is a highly valued social service in every country including Nigeria. Education is the process of facilitating learning, or the acquisition of knowledge, skills, values, morals, beliefs, and habits. It is seen as a key to success in an effort to develop the human and material resources of the country. Education brings about an inherent and permanent change in a person's thinking and capacity to do things. A right to education has been recognized by some governments and the United Nations. Consequently, in most regions, education is compulsory up to a certain age (Darling-Hammond., 2020)[1]. There is even a movement for education reform and in particular for evidence-based education with global initiatives aimed at achieving the Sustainable Development Goal 4 (Richardson, 2011)[2]. That is, to promote quality education for all. Richardson was of the view that education is a nation building activity. Thus, for the development of a country, emphasis should be placed on education, especially in the early stage of the student - primary and secondary education.

Secondary school education is an essential stage of education that acts not only as a bridge between the primary and the tertiary levels of education but also as a backbone of the country's work force (Okoye, 2016)[3]. As regards the students in secondary school 
stage, education helps the students to think, feel, and behave in a way that contributes to their success, and improves not only their personal satisfaction but also their community (Eleje, 2019)[4]. In addition, secondary school education develops the students' personality, thoughts, dealing with others and prepares the students for life experiences. It is therefore necessary to establish a body that will be responsible for its effective implementation process to achieving the desired objectives. Anything short of this will cause the secondary education system to continuously produce half-baked products that will compound Nigeria's economic, social and political problems (Esomonu, 2018)[5].

It is a fact that the success of any educational system depends largely on the caliber of its teachers. That is, the quality of education depends upon ability and efficiency of teachers. If the teachers are well trained, motivated and committed to their profession, learning will be enhanced. The success of teachers in their work has direct implications for the quality of learning of their students (Johnson, 2017)[6]. Teachers are expected to not only to master the subject and various method of teaching but also to show that they are capable of selecting the various study materials according to the teaching goals and varied group of students. Although teaching is actually one of the oldest professions, the requirements for entrance into the teaching profession have not always been as high as those for some other professions (Jackson, 2016)[7]. Many persons have used and still use it as a stepping stone to other profession. Teachers are blamed for not discharging their duties and responsibility adequately and satisfactorily. Furthermore, it is also true that in the profession of teaching, there are some members who have lived up to the desirable level of conduct and service because of interest and high level of professionalism. Profession is an occupation or occupational group that fulfills certain criteria among other things (Hotman, 2010)[8]. It must require training and knowledge, must perform a social service, must have a code of ethics and must have a sense of autonomy and personal responsibilities.

Nevertheless, teaching is a complex and demanding professional task (Eleje \& Esomonu, 2018)[9]. Achieving success in teaching cannot be guaranteed in all cases. Being a teacher is not for the faint of heart. It requires patience, preparedness, flexibility, an open mind and strength. It is a rewarding career, as it gives you the opportunity to change many lives for the better. Gourneau (2010)[10] indicated that attitudes and actions employed by teachers can ultimately make a positive or negative difference to the lives of their students. Moreover, attitude of teachers has been identified to be influenced by factors like gender, social and political control, the workplace, area of residence (Emad \& Dodeen, 2014)[11]. Emad and Dodeen found that female teachers have more positive attitude towards teaching profession as compared to male teachers. Social and political control existing over teaching and the profession, in addition to the economic problem also affect their attitude towards teaching. According to Flores (2001)[12], the workplace plays a crucial role in shaping teacher's attitude, especially of principals and the nature of communication within the school. The area of residence (rural and urban), subject impact (science and arts) and working environment behaviour (public and private sector) also affect teachers' attitude towards the teaching profession.

According to Oluremi and Oyewole (2013)[13], attitude towards profession implies a person's feelings, behaviour and commitment to the profession or job. Therefore, if a teacher is committed and has positive attitude, then it is sure that his/her performance will be fruitful. Saini (2005)[14] had earlier defined attitude as something that change slowly. According to Allport (2016)[15] "an attitude is a mental and neural state of readiness, organized through experience, exerting a directive or dynamic influence upon the individual's response to all objects and situations with which it is related." In expatiating more, Churchill (2016)[16] stated that attitude is a little thing that makes a big difference. An attitude is a positive, negative, or mixed evaluation of an object expressed at some level of intensity. It is an expression of a favorable or unfavorable evaluation of a person, place, thing, or event (James, 2016)[17]. These are fundamental determinants of our 
perceptions of and actions toward all aspects of our social environment. Attitudes involve a complex organization of evaluative beliefs, feelings, and tendencies toward certain actions. Attitude is a vital factor in determining anyone's reaction to any person or thing. Attitude study is therefore, essential in issues like occupation. The attitude of teachers towards teaching in Nigeria seems bleak on the future of the profession. Especially, as teachers attitude towards the teaching profession affects the students' educational performance. The teachers seem unsatisfied with the job. New entrants also find it difficult to settle permanently in the field. Teaching profession is therefore chosen as a last resort. It has considerably suffered as it could not attract the best talents because of the poor pay scale, limited prospect of promotion and insecurity of service particularly in private institutions.

There are various attitudes that secondary school teachers display towards their teaching profession. According to Churchill (2016)[16] it includes; positive, negative, neutral and sikken attitude. A positive attitude means keeping a positive mindset and thinking about the greater good, no matter whatever the circumstances are. A positive attitude has many benefits which affect other kinds of behavior in a good way. A Negative attitude is a kind of attitude that ignores the good things in life and only thinks about whether they will fail. A negative attitude is something that every person should avoid. One with negative attitude often finds a way out of tough situations by running away from it (Kell, 2019)[18]. They often compare themselves with other persons and find the bad in them only. It is an opposite of a positive attitude. Neutral attitude on the other hand is another type of attitude that is common. It is a kind of attitude that ignores the problems of the world. People with such attitude wait for other individuals to take care of their problems. Sikken attitude as well is a type of attitude which is more of a negative attitude and is very destructive. It often reflects the mind's negativity. It is necessary to let go of this kind of attitude for the betterment of the self and the people around you. They are often difficult to be mended because the attitude is deep-rooted within one's personality.

But, for the purpose of this study, the researchers made use of the positive attitude. The researchers decided to investigate on the extent of positive attitude of secondary school teachers because positive attitude means positive thinking (Kirkegaard, 2015)[19]. A positive attitude makes success easy, a negative one makes success pointless (Gecer, 2002)[20]. A person with a positive attitude will explore good things in others and not go after negativity. The people with positive attitude move forward with confidence and optimism and they remain happy and cheerful (Churchill, 2016)[16]. A positive attitude of a teacher draws the students to him and encourages them to do their best, but a teacher with a negative attitude, however, can only compel the students to do their work through fear. Therefore, positive attitude of a teacher will make his performance better and his efforts will be fruitful.

Many studies have been carried out by researchers on the issue of assertiveness of teachers and issues related to teaching profession. A study by Alice (2017)[21] observed that teaching profession had gone down on the scale of respectability causing a number of teachers to drift into different forms of employment. Consequently, Akinduyo (2014)[22] noted that teaching profession has yet to resume professional status unlike the legal, medical and other profession. Some have come out with the findings that people are no longer interested in teaching profession, because of the relatively poor remuneration and low prestige attached to the profession (Alice, 2017; Onyukwu, 2017)[21,23]. Also, Onyukwu (2017)[23] noted an obstacle to teaching attaining full professional status- the lack of effective participation by teachers in decision making of vital educational matters relating to their job.

Although, these afore-mentioned studies focused on the actions of teachers towards the teaching profession, they were conducted in other countries and other parts of Nigeria without mention of Awka south LGA, Anambra state. Nothing has been done to ascertain the attitude of teachers towards the teaching profession in Awka south LGA, Anambra 
state. Hence, an effort is made to assess the outlook of secondary school teachers towards the teaching profession in Awka south Local Government Area (LGA), Anambra state. In the present study, the researchers also tried to find out the possible difference in the attitude of male and female secondary school teachers towards the teaching profession, and if there are any differences between the attitude scores of teachers teaching in urban and rural areas. Therefore, the present study sought answers to these research questions and hypotheses:

\subsection{Research question}

1. What is the attitude of secondary school teachers towards the teaching profession?

\subsection{Hypotheses}

To carry out the study, the researchers tested the following formulated research hypotheses for rejection or otherwise at $5 \%$ level of significance:

Ho 1: There is no significant difference between male and female secondary school teachers attitude towards the teaching profession.

Ho 2: There is no significant difference between urban and rural secondary school teachers' attitude towards the teaching profession.

\section{Method}

The study employed a survey design. This design is considered appropriate for the present study which sought the opinions of secondary school teachers on their attitude towards the teaching profession. The sample of the study comprised of 55 Senior Secondary two (SS2) teachers from 3 urban and 3 rural government secondary schools in Awka south LGA, Anambra state. The instrument used for data collection was a questionnaire titled, Attitude Towards' Teaching as a Career (ATTC). The ATTC was developed by the researchers. The ATTC has two parts, A and B. Section A sought information on the demographic data of the respondents. Section B sought information on the opinion of the respondents regarding the topic of the study and it has one cluster, which sought information on the attitude of secondary school teachers towards the teaching profession. The questionnaire contained 20 items. The ATTC items was structured on four points rating scales of Strongly agree (SA), Agree (A), Disagree(D), Strongly Disagree (SD) with numerical values of 4,3,2 and 1 respectively for positively worded items while negatively worded items will be reversely scored. The ATTC was validated. In testing for the reliability, Cronbach alpha method was used. The instrument was administered to 16 teachers outside the sample of the study. The data obtained were used to calculate the alpha value, which yielded a coefficient value of 0.74 . This shows that the instrument was reliable for the study.

The administration of the ATTC to the teachers was done by the researchers. The researchers made use of the direct delivery approach in which the copies of the ATTC were administered and collected on the spot. In this way, all the copies of the ATTC were recovered. The collected data were analyzed to compute the descriptive as well as inferential statistics used to answer research questions and hypotheses. Analysis was by Statistical Package for Social Sciences version 23 (SPSS v 23.0). A weighted mean score from 2.50 and above was taken as agree; while weighted mean scores below 2.50 was taken as disagree. Mann-Whitney $\mathrm{U}$ test was used to test the hypotheses. A p-value $\leq 0.05$ was taken as significant.

\section{Result and Discussion}

The analysis and findings of the study are presented according to the research questions. Table 1 presented the attitude of secondary school teachers towards the teaching profession. Table 2 presented the mean difference in the attitude of female and male 
teachers towards the teaching profession, while Table 3 present the mean difference between the attitudes scores of teachers teaching in the urban and rural areas.

Research Question 1: What is the attitude of secondary school teachers towards the teaching profession?

Presented in Table 1 is the frequency and mean rating of secondary school teachers' attitude towards the teaching profession.

Table 1. The Mean Rating of the Attitude of Secondary School Teachers towards the Teaching Profession in Awka South LGA, Anambra State

\begin{tabular}{|c|c|c|c|c|c|}
\hline $\mathbf{S} / \mathbf{N}$ & As a teacher & $\mathbf{N}$ & Mean & Std. Deviation & Remarks \\
\hline 1 & $\begin{array}{l}\text { I inspire students to realize and exceed } \\
\text { their potentials. }\end{array}$ & 55 & 3.73 & .449 & Accepted \\
\hline 2. & $\begin{array}{c}\text { I am a great mentor and teacher for the } \\
\text { students }\end{array}$ & 55 & 3.87 & .336 & Accepted \\
\hline 3. & $\begin{array}{l}\text { I instill in students the needs to never } \\
\text { stop learning. }\end{array}$ & 55 & 3.65 & .615 & Accepted \\
\hline 4. & $\begin{array}{l}\text { I maintain a good relationship with my } \\
\text { students. }\end{array}$ & 55 & 3.27 & .827 & Accepted \\
\hline 5. & $\begin{array}{l}\text { I cannot control the class without in- } \\
\text { flicting corporal punishment to disobe- } \\
\text { dient students }\end{array}$ & 55 & 2.84 & 1.229 & Accepted \\
\hline 6. & $\begin{array}{l}\text { I do not follow up to formative assess- } \\
\text { ment. }\end{array}$ & 55 & 1.18 & .611 & Unaccepted \\
\hline 7. & $\begin{array}{l}\text { I do not make use of instructional ma- } \\
\text { terials in my teachings. }\end{array}$ & 55 & 1.18 & .611 & Unaccepted \\
\hline 8. & $\begin{array}{l}\text { I am lackadaisical towards the stu- } \\
\text { dents' academic performance. }\end{array}$ & 55 & 1.00 & .000 & Unaccepted \\
\hline 9. & $\begin{array}{c}\text { I am always available for my students' } \\
\text { questions and consultation. }\end{array}$ & 55 & 3.07 & .900 & Accepted \\
\hline 10. & $\begin{array}{l}\text { I take sufficient time to clarify the } \\
\text { doubts of my students. }\end{array}$ & 55 & 3.11 & .936 & Accepted \\
\hline 11. & $\begin{array}{l}\text { My responsibility towards the students } \\
\text { ends in school. }\end{array}$ & 55 & 1.02 & .135 & Unaccepted \\
\hline 12. & $\begin{array}{l}\text { I complain about the teaching profes- } \\
\text { sion due to the school workload }\end{array}$ & 55 & 3.09 & .800 & Accepted \\
\hline 13. & $\begin{array}{l}\text { I complain about the teaching profes- } \\
\text { sion because of the low pay scale. }\end{array}$ & 55 & 3.93 & .262 & Accepted \\
\hline 14. & I have no self-satisfaction in teaching. & 55 & 1.64 & .930 & Unaccepted \\
\hline 15. & $\begin{array}{l}\text { I cannot make ends meet without pri- } \\
\text { vate tuition. }\end{array}$ & 55 & 2.87 & 1.233 & Accepted \\
\hline 16. & $\begin{array}{l}\text { My duty as a teacher is to equip myself } \\
\text { with the latest technology }\end{array}$ & 55 & 3.11 & .854 & Accepted \\
\hline 17. & $\begin{array}{l}\text { I am proud of my profession irrespec- } \\
\text { tive of other people's feeling towards it }\end{array}$ & 55 & 3.58 & .809 & Accepted \\
\hline 18. & $\begin{array}{l}\text { I am more interested in my salary than } \\
\text { the students }\end{array}$ & 55 & 1.29 & .685 & Unaccepted \\
\hline 19. & I consider teaching a noble profession & 55 & 3.06 & .359 & Accepted \\
\hline 20. & Teaching is a challenging profession & 55 & 3.27 & .952 & Accepted \\
\hline
\end{tabular}




\section{GRAND MEAN}

2.63

Accepted

The result presented in Table 1 indicated that the majority of the secondary school teachers have a positive attitude towards the teaching profession as their response to items $1,2,3,4,5,9,10,12,13,15,16,17,19$ and 20 were all positive and above the accepted mean of 2.50. The items $6,7,8,11,14$, and 18 were rejected by the respondents as their mean are all below the accepted mean mark of 2.50. The cluster mean is 2.63. As this study investigated the attitude of secondary school teachers towards the teaching profession in Awka south Local Government Area (LGA), Anambra state, the result of the analysis as presented in Table 1 showed that the secondary school teachers in Awka south LGA possess a positive attitude towards the teaching profession irrespective of the challenges and difficulties that comes with teaching; the teachers also consider teaching as a noble profession. The findings also revealed that despite the low pay scale of teachers and the school workload, the teachers still inspire and motivates students to realize and exceeds their potentials and the teachers love their profession irrespective of other peoples' feelings towards it. This study finding is in line with that of Rohini (2012)[24]. He conducted a research that assessed the attitude of secondary school teachers towards the teaching profession at different levels, to compare attitude of teachers towards teaching profession at different levels and to check the effects of teachers training at different levels on attitude towards teaching profession. The result obtained showed that the primary, secondary, higher secondary and college teachers are having higher attitude towards teaching profession.

\subsection{Hypothesis 1}

There is no significant difference between male and female secondary school teachers attitude towards the teaching profession.

In Table 2 is presented the mean rank and sum of ranks of teachers' attitude towards the teaching profession in Awka south LGA for the male and female teachers.

Table 2. Mean Ranks of the Secondary School Teachers' Attitude towards the Teaching Profession Based on Gender

\begin{tabular}{ccccc}
\hline & Gender & N & Sum of Ranks & Mean Rank \\
\hline Teachers' Attitude & Male & 23 & 835.50 & 36.33 \\
& Female & 32 & 704.50 & 22.02 \\
& Total & 55 & & \\
\hline
\end{tabular}

The Table 2 indicates in overall, that the male teachers can be considered as having the higher positive attitude towards the teaching profession. That is, the groups with the highest mean rank. Statistical result of the Mann-Whitney $U$ test of significance difference in the mean ranks of male and female teachers' outlook towards the teaching profession based on gender is shown in Table 3.

In Table 3 is presented the actual significance value of the test. Specifically, it provides the test statistic, $U$ statistic, as well as the asymptotic significance (2-tailed) $p$-value of the difference in the teachers' outlook towards the teaching profession based on gender.

Table 3. The Test Statistic, $U$ Statistic, and Asymptotic Significance (2-tailed) $p$-value

\begin{tabular}{cc}
\hline \multicolumn{3}{c}{ Test Statistics $^{\mathbf{a}}$} \\
\hline Mann-Whitney U & 176.500 \\
Wilcoxon W & 704.500 \\
Z & -3.287 \\
Asymp. Sig. (2-tailed) & .001 \\
\hline
\end{tabular}

a. Grouping Variable: Gender 
As seen in Table 3, the observed mean rank difference in the attitude towards teaching profession for the male and female teachers in secondary schools was statistically significantly $(U=176.500, p=.001)$. This implied that, the outlook of male secondary school teachers in Awka south LGA towards' the teaching profession is significantly better than their female counterpart. This study outcome contradicts the previous result by Emad and Dodeen (2014)[11] that female teachers have more positive attitude towards teaching profession as compared to male teachers. This study finding also contradicts that of Shaukat and Riasal (2011)[25]. They conducted a research which indicated that the secondary school teachers do not possess high positive attitude towards the teaching profession. The result they obtained showed that the score of female teachers was higher than the male teachers. According to Shaukat and Riasal, this might be as a result of low salaries earning of the teachers, which they pointed specifically. Nevertheless, with the scope of the present study, it was pointed out that teaching is a noble profession and also teaching is a challenging profession. Thus, despite the challenges and noble profession that comes with teaching, teachers might loss the teaching attitude in the teaching profession as pointed out by Shaukat and Riasal (2011)[25].

\subsection{Hypothesis 2}

There is no significant difference between urban and rural secondary school teachers' attitude towards the teaching profession.

In Table 4 is presented the mean rank and sum of ranks of urban and rural secondary school teachers' attitude towards the teaching profession.

Table 4. Mean Ranks of the Attitude of Secondary School Teachers' towards the Teaching Profession Based on Teachers' Location

\begin{tabular}{ccccc}
\hline & Teachers' Location & N & Sum of Ranks & Mean Rank \\
\hline Teachers' attitude & Urban & 30 & 474.00 & 15.80 \\
& Rural & 25 & 1066.00 & 42.64 \\
& Total & 55 & & \\
\hline
\end{tabular}

Generally as seen in Table 4, the teachers in rural location can be considered as having the higher positive outlook towards the teaching profession. That is, the groups with the highest mean rank. Statistical result of the Mann-Whitney U test of significance difference in the mean ranks of urban and rural teachers' attitude towards the teaching profession is represented in Table 5.

In Table 5 the real significance value of the test statistic, $U$ statistic, as well as the asymptotic significance (2-tailed) $p$-value of the difference in the attitude of secondary school teachers towards the teaching profession based on their location (i.e., urban and rural) is portrayed.

Table 5. The Test Statistic, $U$ Statistic, and Asymptotic Significance (2-tailed) $p$-value

\begin{tabular}{cc}
\hline & Test Statistics $^{\mathrm{a}}$ \\
\hline Mann-Whitney U & 9.000 \\
Wilcoxon W & 474.000 \\
Z & -6.205 \\
Asymp. Sig. (2-tailed) & .000 \\
\hline
\end{tabular}

a. Grouping Variable: Teachers' Location

As seen in Table 5, the observed mean rank difference in the outlook of teachers towards the teaching profession for the teachers in urban and rural secondary schools in Awka south LGA was statistically significantly $(U=9.000, p=.000)$. This implied that, 
teachers in rural location have a significantly higher positive outlook towards the teaching profession than those in rural location. This study result is possible since the rural environment will afford the teachers the opportunity of lesser economic expenditures. According to Trentham and Blackburn (2010)[26], the area of residence can affect the attitude of secondary school teachers that is when teachers have no money to transport themselves to their respective schools, they lose focus and seek for other higher revenue making business, so as to cater for their needs, thereby leaving their present duty.

Certain strength and limitations are encountered in the course of the study. This study is probably the first study in Awka south local government area on attitude of secondary school teachers towards the teaching profession.

\section{Conclusion}

In consideration to the study findings, the researchers concluded that the secondary school teachers in Awka South LGA possessed a positive attitude towards the teaching profession. The researchers also concluded that male teachers and teachers in rural location of the secondary schools in Awka south LGA have a high positive significant attitude towards the teaching profession. The researcher recommends that a similar study could be replicated in other local government areas of the state, and a study can be done to investigate variables affecting attitude of secondary school teachers.

\section{Recommendations}

1. Based on the findings of the study, the following recommendations were made.

2. The government and teacher organization should see to the training, retraining and motivation of secondary school teachers, for when they are well-trained and motivated, they will be more committed and learning will be enhanced.

3. The conditions of service of teacher should be improved and enhanced as in other professions so as to make teachers not to feel inferior or neglected compared with workers in other professions interns of payment of salaries and allowances, recognition and granting opportunities.

4. Teaching in rural area should be attractive, such as hardship allowances, financial incentives, travel allowance, special study level etc.

5. Employment of teachers by the government through the ministry of education should be strictly based on merit so as to make it possible for only those who studied the course to be appointed.

\section{References}

[1] Darling-Hammond., L. (2020). The right to learn and the advancement of teaching: Research, policy, and practice for democratic education. Educational Reseacher, 25(6), 5-17.

[2] Richardson, J. (2011). The content of language teaching. London. UK. Cambridge University Press.

[3] Okoye, F. (2016). Basic concept of education. Retrieved my 9. 2016. From http.//www.Linked in.com.

[4] Eleje, L.I. (2019). Choice of economics as a subject: Gender influence on senior secondary students. International Journal of Scientific and Education Research, 3(1), 75-87.

[5] Esomonu, N.P.M., Ikeanumba, B.C., \& Eleje, L.I. (2018). Effect of economic recession on tertiary education in Nigeria. International Journal of Scientific and Education Research, 2(2), 126-138. http://ijsernet.org/

[6] Johnson, D. (2017). Roles of teachers and learners. New York. USA. Oxford University Press.

[7] Jackson., P. (2016). What is teaching? In R. S. Peters (ed.) The Philosophy of Education. London: Routledge and Kegan Paul.

[8] Hotaman., D. (2010). SÕnÕf yönetimi sürecinde sergilenen ö $\div$ retmen davranÕúlarÕnÕn belirlenmesi (Determining teacher behavior demonstrated in the Classroom Management Process), MEB Orta Ö-retimde Yeniden Ya pÕlanma Sempozyumu, 20-22, AralÕk, Ankara

[9] Eleje, L.I., \& Esomonu, N.P.M. (2018). Test of achievement in quantitative economics for secondary schools: Construction and validation using item response theory. Asian Journal of Education and Training, 4(8), 18-22. Doi: 10.20448/journal.522.2018.41.18.28

[10] Gourneau., J. (2010). Teachers belief and knowledge in D.C. Berliner \& R.C. Calfee (Eds) Handbook of educational psychology (PP. 709-725). New York: Simon and Schuster. 
[11] Emad., M., \& Dooden, H. A. (2014). Attitude of pre-service teachers towards persons with disabilities: Prediction for the success of inclusion: college student's Journal, 37.

[12] Flores., M. A. (2001). Person and Context in Becoming a New Teacher. Journal of Education for Teaching, 27(2).

[13] Oluremi, O.F and Oyewole., B.K. (2013). Supervision for quality assurance in universal basic education programme in Nigeria. Mediterranean Journal of social sciences. 4 (6) 447-452.

[14] Saini, I., \& Chiú, V. (2005). Pedagogia contemporană. Pedagogia pentru competenǴe. Cluj-Napoca: Editura Casa CărǴii de ùtiinǴă.

[15] Allport., G. U. (2016). Attitude. In: C. Murchison (ed.). Handbook of Social Psychology. Clark University Press.

[16] Churchill., w. (2016) Types of attitude. Effects of multimedia learning principles and an instructional approach. Interactive learning environment 1-6.

[17] James, N. (2016). Lessons on positive thinking and leadership from Confucius. International Journal of GSTF Business Review, 1, 99-206.

[18] Kell, H. J. (2019). Those who can teach (7 $7^{\text {th }}$ ed.). Boston Toronto: Houghton Mifflin Company.

[19] Kirkegaard, E.W. (2015). The power of positive thinking. Fireside: New York.

[20] Gecer., A. K. (2002). Ogretmen yakinliginin ogrencilerin basarilari, tutumlari ve gudulenme duzeyleri uzerindeki etkisi (The effect of teacher immediacy on students' performance, attitude and motivation). Unpublished doctoral, University of Ankara, Ankara.

[21] Alice., E. (2017). The Nigerian education: Past, present, and future, Lagos, Thomas Nelson (Nig.) Ltd.

[22] Akinduyo, T. A., \& Fafunwa, A.B. (2014). Professionalization of teaching in A. A. Adaragba [ED], Philosophy for Nigeria education. (Pp.88). Ibandan. 23).

[23] Onyukwu, J. (2017). Strategies for professionalizing teaching in Nigeria. In A, Ndu, et,al (Ed) Educational policy and implementation in Nigeria. The Nigerian Association for educational administration and planning. (NAEAP).

[24] Rohini, T.P. (2012). A study of attitude of teachers towards teaching profession at different level, International Multidisciplinary e-journal, 1(5), 24-30.

[25] Shaukat, H., Riasal, A., Saeed, M. K., Muhammad, R., \& Qadaeer, M. (2011). Attitude towards the teaching profession. International Journal of Academic Research, 3(1), 111.

[26] Trentham., L., \& Blackburn., J. (2010). Rural teachers and teacher education. Eastern Education Journal, 14,19-23. 